\title{
PORT GOVERNANCE IN THE UK: PLANNING WITHOUT POLICY
}

\author{
Jason Monios \\ Transport Research Institute, Edinburgh Napier University \\ Merchiston Campus, Edinburgh, EH10 5DT, United Kingdom \\ Email: j.monios@napier.ac.uk
}

This is the pre-published version of the text. The final published paper can be found at:

Monios, J. (2017). Port governance in the UK: planning without policy. Research in Transportation Business and Management. 22: 78-88.

DOI: $10.1016 /$ j.rtbm.2016.10.006

\begin{abstract}
The UK's highly privatised port system means that, while many of the issues in the port governance literature relevant to port concessions do not arise here, the respective roles of harbour authorities and port operators continue to be questioned. The concern in the UK is whose role it should be to monitor the capacity and service quality of the port sector, including how to govern the ways in which the different classes of port stakeholder interact.

This paper describes and discusses the UK port sector, the main ports and cargo types, the governance system and recent developments. Recent changes in national policy are reviewed and potential new developments in governance are considered, reflecting on how the UK case represents some key theoretical considerations regarding infrastructure governance within a modern political system favouring private ownership and operation of the transport sector.
\end{abstract}

Key words: UK; port governance; private; trust; container; policy; planning 


\section{Introduction}

The UK is unusual in its highly privatised port system, with approximately $69 \%$ of tonnage handled by privately owned and operated ports. The result is that many of the discussions in other countries about port concessions do not arise here. Yet the role of harbour authorities vis-à-vis port operators and whether and how they should be regulated continues to be questioned. The challenge in the UK is to identify shortcomings in the sector and decide the best way for port stakeholders (whether government, port operators, port users or the wider community) to achieve their goals of a well-functioning and competitive port sector to support the economy.

This paper presents an overview of the UK port sector and outlines the governance arrangements, including private, trust and municipal ports. A brief recap on the privatisation of much of the UK port sector in the 1980s and 1990s is provided, before moving on to more recent developments. A number of recent port expansions are discussed and the changing dynamics in the sector are analysed. Current debates in UK port governance are reviewed and the paper reflects on the possible governance reforms that could be feasible and the political difficulty of achieving them.

\section{The UK port system}

The vast majority of ports and harbours in the UK deal with leisure and fishing craft. Only 161 ports currently report commercial traffic, with $98 \%$ of this traffic being handled by those ports classed as major (53 ports) and the remainder handled by minor ports (108 ports). Total tonnage handled at UK ports in 2014 was 503.2m tonnes, relatively stable for the last few years since the downturn in 2008 (Figure 1). ${ }^{1}$

\footnotetext{
${ }^{1}$ Unless otherwise stated, all statistics were sourced from DfT (2015).
} 


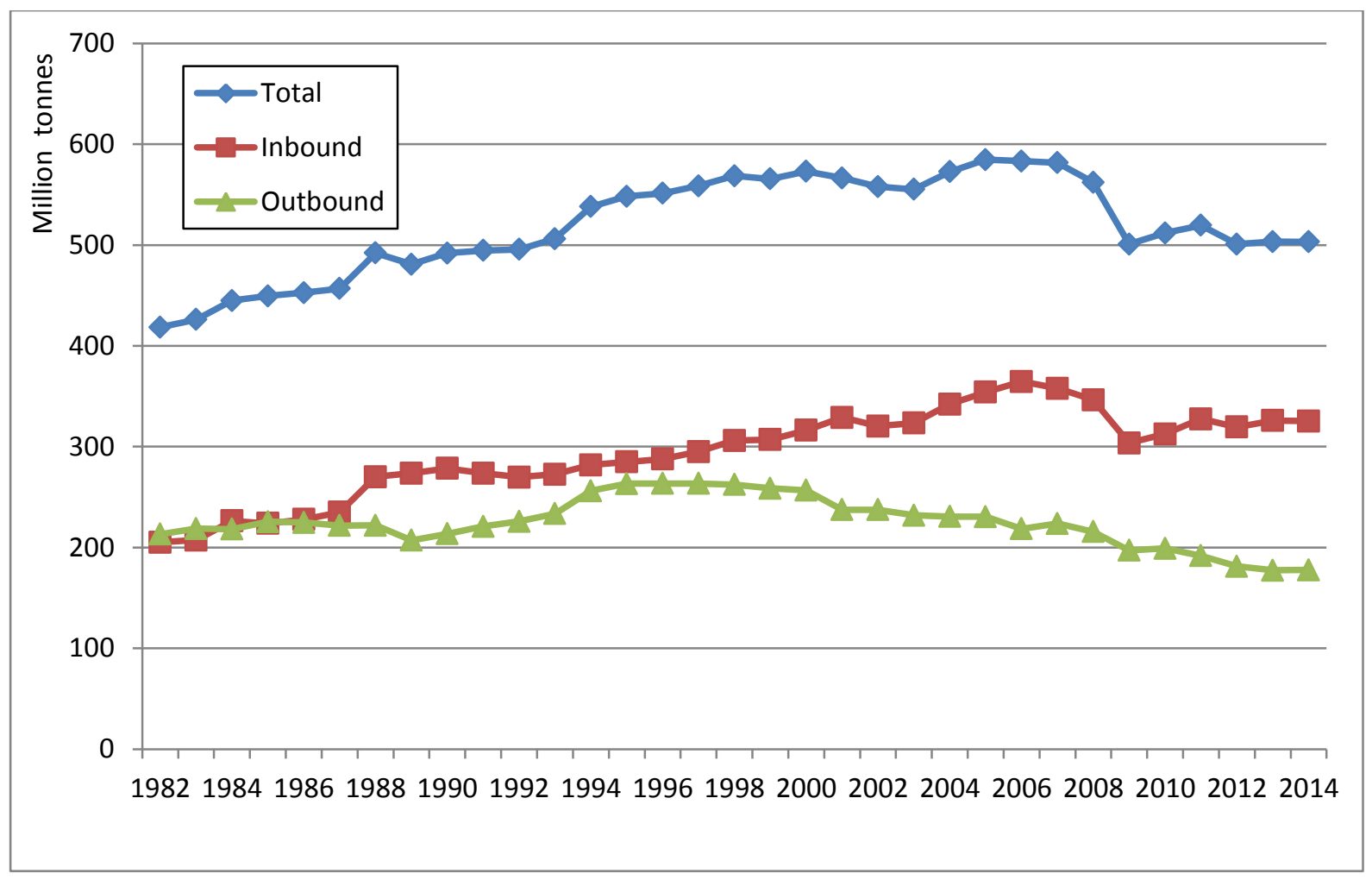

Figure 1. Total tonnage UK ports 1982-2014

Source: DfT (2015) 


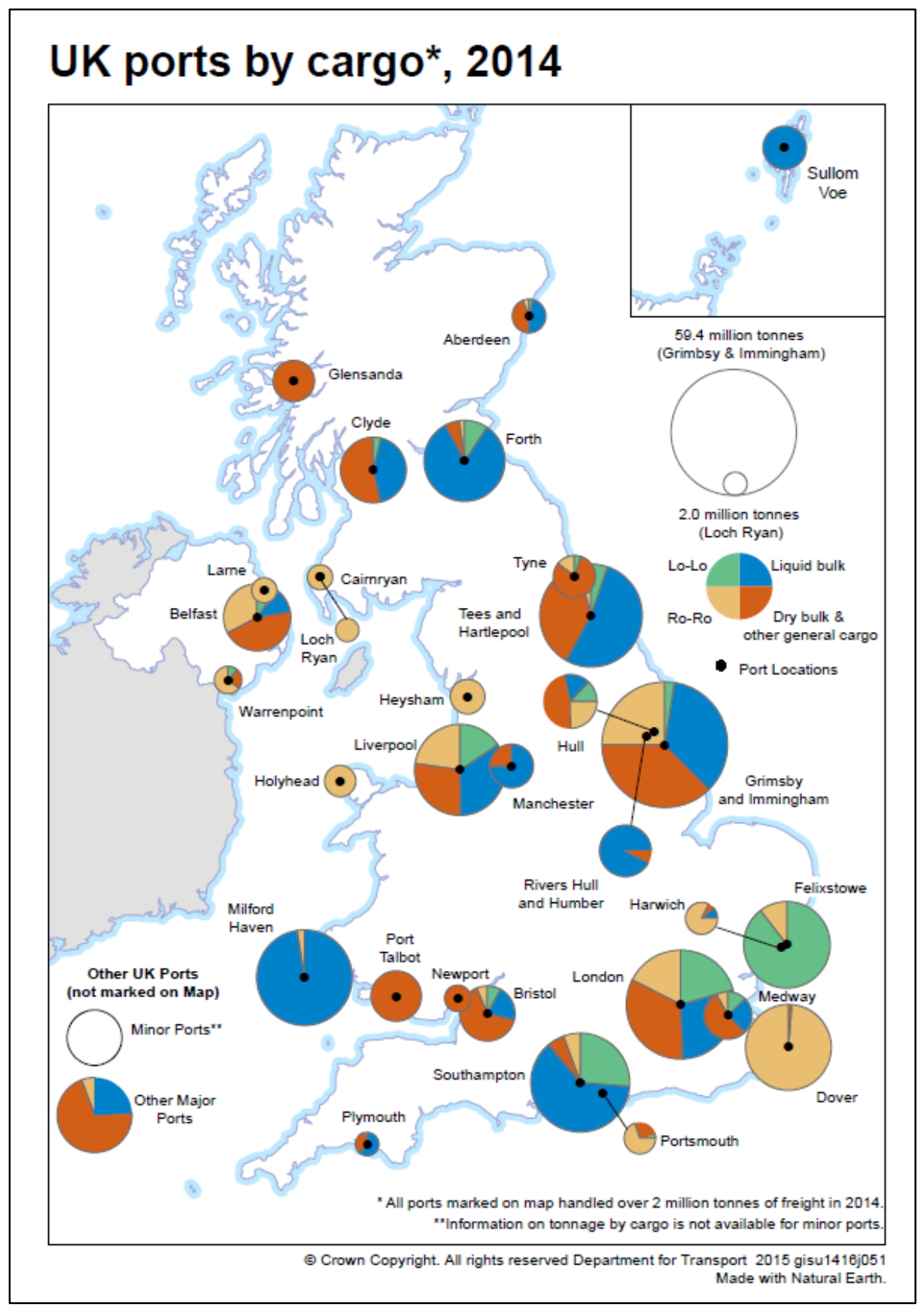

Figure 2. UK ports by cargo 2014

Source: DfT, 2015

The traffic types can be broken down into liquid bulk (38\%), dry bulk (25\%), RoRo (20\%), LoLo (12\%) and general cargo (4\%) and the traffic locations are mapped in Figure 2. Liquid bulk remains the dominant category, based on crude oil and oil products, while dry bulk is almost $50 \%$ coal. The two markets exhibit divergent trends, with crude oil declining due to the closure of UK oil refineries and coal imports rising over the last decade, although 
dropping in 2014 in response to recent changes in demand for biomass fuels in formerly coalfired power stations, reflected in the rise of the "other dry bulk" category. Both RoRo and LoLo continue to rise. General cargo has declined, mostly due to the decline of forestry product imports, while steel has remained stable. Other market segments include support work for the offshore oil rigs and, in recent years, renewables such as windfarms and tidal energy developments (DfT, 2015).

Table 1 lists the top 20 port areas by tonnage, accounting for $87 \%$ of total UK tonnage. The port names used in the table and related statistics are based on the port groupings decided by the UK DfT. These are sometimes single ports and sometimes grouped based on rivers and harbour areas which may include several different owners and operators. This has implications both for the identification of the harbour authority vis-à-vis individual port and terminal operators as well as the tonnage figures which sometimes relate to more than one port besides the one actually named. The table names the major port owners in each grouping, which account for the majority of the tonnage.

In order to interpret the official statistics, a distinction must be observed between port owners (owners of a specific port area and usually operating terminals within the port) and non-landowning terminal operators (operating individual terminals or wharves within a port area, sometimes under contract or concession from or part of a joint venture with the port owner). Since the privatisation processes discussed in section 3.1, in many cases the same private company is the harbour authority, port land owner and port operator, but in other cases wharves or terminals may be operated by individual companies within an area. This simplification is particularly relevant for the Thames and Humber estuaries. For example, the Port of London Authority has harbour jurisdiction over many ports on the Thames with different owners/operators, such as major container ports Tilbury (Forth Ports) and London Gateway (DP World) and smaller ports Purfleet (Cobelfret Group), Dartford (C.RO Ports Dartford Ltd) and Dagenham (Stolthaven Terminals). Also, the Port of London Authority's statutory harbour jurisdiction does not extend fully into London Gateway, for which the authority is with the port owner and operator DP World. Similarly, in some of Associated British Ports' (ABP) ports on the Humber there are facilities that have been built and operated separately by its tenants, sometimes as joint ventures with ABP, sometimes independently. Thus, while this paper focuses for the most part on the higher levels of the governance hierarchy (e.g. the relationship between the government, harbour authorities and major port owners/operators), an important governance question concerns the way operators 
of small terminal facilities (or those wishing to operate facilities) deal with harbour authorities and port landowners (which in many cases are the same organisation). 
Table 1 . Top 20 UK port areas by tonnage, 2014 (million tonnes)

\begin{tabular}{|c|c|c|c|c|c|c|c|}
\hline $\begin{array}{l}\text { Port name/ } \\
\text { grouping }\end{array}$ & Definition of the grouping area & $\begin{array}{c}\text { Port } \\
\text { ownership }\end{array}$ & $\begin{array}{l}\text { Harbour } \\
\text { authority }\end{array}$ & $\begin{array}{l}\text { Owner of the major port(s) in } \\
\text { the grouping }\end{array}$ & Main cargo types & $\begin{array}{l}\text { Tonnage } \\
\text { (million) }\end{array}$ & $\begin{array}{c}\text { Percent } \\
\text { of UK }\end{array}$ \\
\hline $\begin{array}{l}\text { Grimsby \& } \\
\text { Immingham }\end{array}$ & $\begin{array}{l}\text { Grimsby and Immingham Harbours, including Killingholme, on south } \\
\text { side of the River Humber }\end{array}$ & \multicolumn{2}{|c|}{ Private } & $\mathrm{ABP}$ & RoRo, oil products, crude oil, coal & 59.3 & 11.8 \\
\hline London & $\begin{array}{l}\text { River Thames between Teddington and the North Sea (excluding the } \\
\text { River Medway). Includes Tilbury, London Gateway, Purfleet, Dartford } \\
\text { and Dagenham. }\end{array}$ & Private & 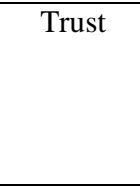 & $\begin{array}{l}\text { Tilbury (Forth Ports), London } \\
\text { Gateway (DP World), Purfleet } \\
\text { (Cobelfret Group), Dartford } \\
\text { (C.RO Ports Dartford Ltd), } \\
\text { Dagenham (Stolthaven Terminals) }\end{array}$ & $\begin{array}{l}\text { Oil products, other dry bulk, containers, RoRo, } \\
\text { agricultural products, ores, forestry products }\end{array}$ & 44.5 & 8.8 \\
\hline $\begin{array}{l}\text { Tees and } \\
\text { Hartlepool } \\
\end{array}$ & $\begin{array}{l}\text { River Tees, including Middlesbrough, Billingham and Redcar and } \\
\text { Hartlepool Harbour }\end{array}$ & \multicolumn{2}{|c|}{ Private } & PD Ports & $\begin{array}{c}\text { Crude oil, coal, ores, iron and steel, oil products, } \\
\text { other liquid bulk, containers, other dry bulk, } \\
\text { liquefied gas }\end{array}$ & 39.5 & 7.9 \\
\hline Southampton & $\begin{array}{l}\text { Southampton Water and Rivers Itchen and Test, including Fawley and } \\
\text { Hamble and Southampton Container Terminals }\end{array}$ & \multicolumn{2}{|c|}{ Private } & ABP & Crude oil, oil products, containers, RoRo, cruise & 36.7 & 7.3 \\
\hline $\begin{array}{l}\text { Milford } \\
\text { Haven } \\
\end{array}$ & Milford Haven, including Pembroke Dock and Pembroke Port & \multicolumn{2}{|c|}{ 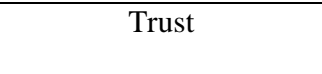 } & Milford Haven Port Authority & Oil products, crude oil, liquefied gas & 34.3 & 6.8 \\
\hline Liverpool & $\begin{array}{l}\text { River Mersey eastwards to \& excluding Garston \& the Manchester } \\
\text { Ship Canal (includes Seaforth, Bromborough \& Tranmere) }\end{array}$ & \multicolumn{2}{|c|}{ Private } & Peel Ports & $\begin{array}{l}\text { Crude oil, RoRo, containers, agricultural products, } \\
\text { oil products, coal, other dry bulk, ores, passengers }\end{array}$ & 31.0 & 6.2 \\
\hline Felixstowe & $\begin{array}{l}\text { Felixstowe Harbour } \\
\end{array}$ & Private & Trust & $\mathrm{HPH}$ & Containers, RoRo & 28.1 & 5.6 \\
\hline Dover & Dover Harbour & \multicolumn{2}{|c|}{ Trust } & Dover Harbour Board & RoRo, passengers & 27.6 & 5.5 \\
\hline Forth & $\begin{array}{l}\text { Forth estuary including Houndpoint, Grangemouth, Leith, Rosyth and } \\
\text { Braefoot }\end{array}$ & \multicolumn{2}{|c|}{ Private } & Forth Ports & Crude oil, oil products, containers, liquefied gas & 24.6 & 4.9 \\
\hline Belfast & Belfast Harbour & \multicolumn{2}{|c|}{ Trust } & Belfast Harbour Commissioners & $\begin{array}{l}\text { RoRo, coal, other dry bulk, agricultural products, } \\
\text { oil products, containers, passengers }\end{array}$ & 16.8 & 3.3 \\
\hline Clyde & $\begin{array}{l}\text { River Clyde, including Clydeport, Hunterston and Ardrossan, and } \\
\text { those on Loch Fyne and Loch Long }\end{array}$ & \multicolumn{2}{|c|}{ Private } & Peel Ports & Coal, crude oil, oil products & 16.2 & 3.2 \\
\hline Bristol & Avonmouth and along River Avon & \multicolumn{2}{|c|}{ Private* } & Bristol Port Company & $\begin{array}{l}\text { Coal, oil products, other dry bulk, agricultural } \\
\text { products }\end{array}$ & 11.4 & 2.3 \\
\hline Hull & Hull Harbour on the north side of the River Humber & \multicolumn{2}{|c|}{ Private } & $\mathrm{ABP}$ & $\begin{array}{l}\text { Other dry bulk, other liquid bulk, containers, coal, } \\
\text { forestry products, passengers }\end{array}$ & 10.9 & 2.2 \\
\hline $\begin{array}{l}\text { Rivers Hull } \\
\text { and Humber }\end{array}$ & $\begin{array}{c}\text { River Hull and River Humber, including New Holland and Tetney but } \\
\text { excluding Hull and Grimsby \& Immingham }\end{array}$ & \multicolumn{2}{|c|}{ Private } & $\mathrm{ABP}$ & Crude oil & 10.0 & 2.0 \\
\hline Port Talbot & Port Talbot & \multicolumn{2}{|c|}{ Private } & ABP & Ores, coal & 9.5 & 1.9 \\
\hline Medway & $\begin{array}{l}\text { Rivers Medway \& Swale \& tributaries, including Sheerness, } \\
\text { Thamesport, Rochester, Chatham, Ridham Dock \& Queenborough }\end{array}$ & \multicolumn{2}{|c|}{ Private } & $\begin{array}{l}\text { HPH (Thamesport), Peel Ports } \\
\text { (Sheerness, Chatham) }\end{array}$ & $\begin{array}{l}\text { Other dry bulk, oil products, forestry products, } \\
\text { containers }\end{array}$ & 8.5 & 1.7 \\
\hline Sullom Voe & $\begin{array}{l}\text { Sullom Voe } \\
\end{array}$ & \multicolumn{2}{|c|}{ Municipal } & Shetland Islands Council & Crude oil & 7.2 & 1.4 \\
\hline Manchester & Manchester Ship Canal & \multicolumn{2}{|c|}{ Private } & Peel Ports & Oil products, other liquid and dry bulk & 7.1 & 1.4 \\
\hline Tyne & River Tyne, including Newcastle & \multicolumn{2}{|c|}{ Trust } & Port of Tyne Authority & Coal, other dry bulk & 6.7 & 1.3 \\
\hline Glensanda & Glensanda (aggregate quarry, export only) & \multicolumn{2}{|c|}{ Private } & Foster Yeoman Ltd & Other dry bulk & 6.3 & 1.3 \\
\hline & & \multicolumn{4}{|c|}{ 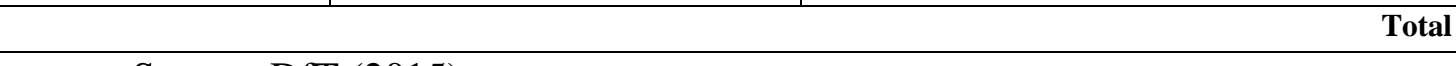 } & 436 & 87 \\
\hline
\end{tabular}

Source: DfT (2015)

* Owned by the municipality but the private operator has a 150 -year lease so it is effectively privatised 
The UK container sector handled $9.5 \mathrm{~m}$ TEU in 2014. The top four container ports (Felixstowe - 4.1m TEU, Southampton - 1.9m TEU, London Tilbury - 1.1m TEU and Liverpool - 666,000 TEU) have remained stable while Medway Thamesport (which battled Liverpool for fourth place for most of the decade) has now declined severely from a peak of 773,000 TEU in 2008 to only 179,000 TEU in 2014 (Figure 3). The port has now lost its last major container service and Hutchison Port Holdings (HPH) is looking to redevelop the terminal for other cargoes such as steel. The rise of Teesport is the other significant change, moving from $15^{\text {th }}$ place in 2000 to $5^{\text {th }}$ in 2014 , with 304,000 TEU, but still a long way off entering the top four (Figure 4).

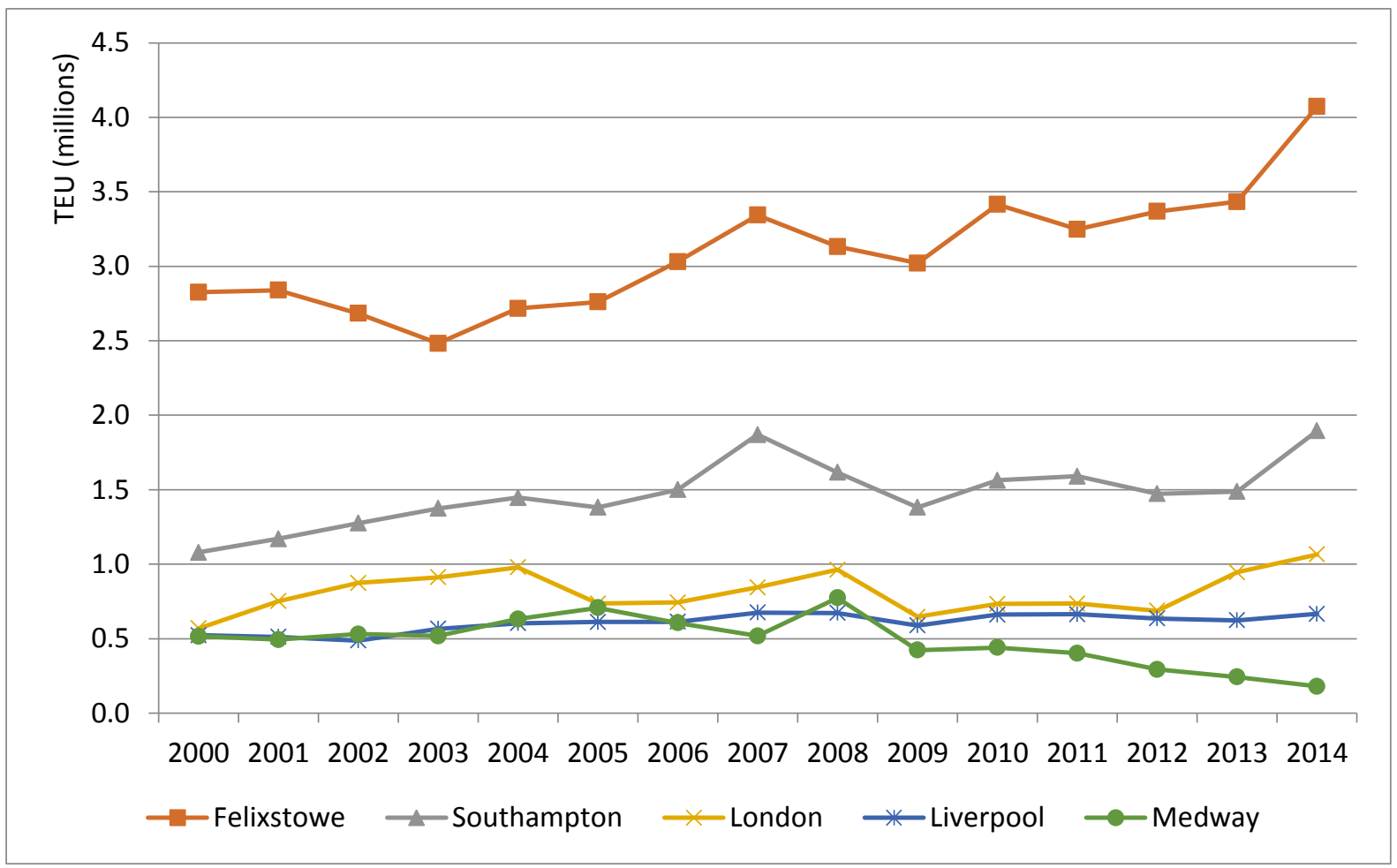

Figure 3. UK major container ports 2000-2014, million TEU

Source: DfT (2015)

Dover in the southeast remains by far the major RoRo port $(34 \%)$ due to its traffic with France, followed by Grimsby and Immingham for other European destinations. Ferry routes with Ireland maintain the RoRo traffic with Holyhead and Liverpool while Cairnryan and Loch Ryan (opened in 2012 just north of Cairnryan as a replacement for the Stranraer service) in southwest Scotland provide RoRo connections with Northern Ireland. Breaking down UK traffic by freight and non-freight units, almost half were actually non-freight units, 
including 25\% passenger cars and busses and $18 \%$ trade vehicles. UK ports also served $65.9 \mathrm{~m}$ passengers, the majority $42.7 \mathrm{~m}$ domestic passengers. Almost half of these were river ferries, $18.6 \mathrm{~m}$ were inter-island ferries, e.g. Isle of Wight and Scotland, and the remainder domestic sea crossings e.g. to Northern Ireland, Orkney and Shetland. UK ports also handled $21.3 \mathrm{~m}$ international ferry passengers, mostly to France but also Belgium and the Netherlands. $1.8 \mathrm{~m}$ cruise passengers were also recorded, mostly for Southampton (DfT, 2015).

As an island nation, the majority of traffic (80\%) at UK ports is international, with $42 \%$ of major port traffic with EU countries. Feeder movements of containers and transport of oil products account for the domestic traffic, while passenger movements between Scotland and Northern Ireland also count as domestic. It was estimated that in 2013 the UK port sector employed 118,200 people and contributed £7.7bn to the economy (Oxford Economics, 2015).

\section{Port governance in the UK}

Due to the devolved political structure in the UK, public responsibility for ports is spread across different jurisdictions. All international shipping remains within the purview of the UK government, while Scotland and Northern Ireland have responsibility for their own ports. The UK government covers ports in both England and Wales, although the Welsh government has responsibility for many related issues such as transport and land-use planning. Much of the structure and governance of UK ports was already set in place before these devolution processes occurred in the late 1990s, therefore the role of government in port governance remains quite similar in all jurisdictions. Therefore, references to UK port policy can in most cases be taken to refer to all of the UK; while specific policy documents are produced for each of the three port jurisdictions (England and Wales, Scotland, Northern Ireland), the policy documents for the latter two are general transport policy documents without specific port policies.

There are three types of port in the UK system: private, trust and municipal. Privately owned ports tend to be the largest and particularly the container ports. Some of these were already private but most were public ports that were privatised in the 1980s and 90s (see next section). 15 of the top 20 ports by tonnage in 2014 are privately owned. Trust ports were each established by their own Act of Parliament and are therefore subject to specific statutes. Being operated by a trust rather than reporting to shareholders, any profit is reinvested in the port. There are over 100 trust ports in the UK, but only 20 with an annual turnover exceeding $£ 1 \mathrm{~m}$ (House of Commons, 2013). Municipal ports represent the majority of UK ports, owned 
and operated by local authorities, and generally focusing on leisure craft although some do handle significant amounts of commercial traffic.

While it was the Conservative government (1979-1997) that conducted the privatisation of UK ports, many of the policy documents discussed in the following sections were in fact produced by the Labour government (1997-2010), evidence of a relatively unchanged government position on the UK port sector across several decades.

\subsection{Private ports}

The privatisation of a number of major UK ports in the 1980s and 1990s has been reported in detail by previous authors (Thomas, 1994; Baird, 1995; Goss, 1997; Saundry \& Turnbull, 1997; Baird and Valentine, 2007). There were two processes. First, several major ports that had been taken into public ownership at the end of the Second World War under the British Transport Docks Board (BTDB) were renamed Associated British Ports (ABP) in 1982, 49\% shares sold in 1983 and the remainder in 1984. ABP remains the largest port group in the country, owning 21 ports and accounting for around a quarter of UK tonnage, including the ports of Grimsby and Immingham, Hull and Southampton. A number of ferry ports (e.g. Stranraer, Holyhead, Harwich) were also sold in the mid-1980s. Second, a number of the largest trust ports were sold in the early 1990s. As trust ports are constituted by their own Acts of Parliament, new legislation was required which was brought forth as the Ports Act 1991 (see next section).

Not only were the port businesses and land sold in their entirety rather than utilising a concession model to bring private operational experience into the sector, there is significant evidence that the ports were sold at low prices (Thomas, 1994; Baird, 1995; Goss, 1997; Pettit, 2008). Farrell (2013) notes that the management buyout model preferred in most instances to share flotation was one reason for both low prices achieved and lack of private operator interest. Moreover, unlike a concession model which would involve a port authority and a port operator, the privatised port company was in most cases given responsibility for the regulatory roles within the harbour, such as providing pilotage and ensuring safe navigation. A distinction should be noted between Statutory Harbour Authorities (responsible for all vessel movements and protection of the marine environment, including functions such as dredging and the provision of navigation aids) and Competent Harbour Authorities (responsible only for the provision of pilotage services), yet in most cases they are the same organisation. Competent Harbour Authorities were created by the Pilotage Act 1987 and 
more recently the Marine Navigation Act 2013 included provision to reverse the process and remove Competent Harbour Authorities status. This situation could, depending on the size of the harbour area and the likelihood of another company seeking to construct port facilities, lead to issues of monopoly and anti-competitive practices. Complications have arisen on the east coast of Scotland with Forth Ports being the harbour authority for the Forth estuary and Babcock needing permission from them for dredging the channel to their own proposed container terminal at Rosyth. There is also the issue that, while total capacity may be sufficient in the Forth, there has been significant criticism of the quality of the service offered at Grangemouth in addition to its restrictions in the size of vessel it can handle. Thus the benefits of competition in the Forth might be seen to outweigh the economies of scale from a single container terminal.

It is important to recognise that some ports have been private for many years, such as the UK's busiest container port Felixstowe, opened in 1886 by a local company and since 1991 owned and operated by HPH. The port of Liverpool was, like the ports discussed in the next section, originally a trust port, but in 1971 in order to avoid bankruptcy the Mersey Docks and Harbour Board was corporatized as the Mersey Docks and Harbour Company (a mixed public-private sector company including around 20\% UK government shareholding, relinquished in 1998 - Baird and Valentine [2007]). In 2005 it was acquired by Peel Holdings. Many of the privatised ports have since changed hands again and now there are a handful of major port groups operating across the UK. With Felixstowe and Liverpool already private beforehand, then the privatised $\mathrm{ABP}$ accounting for many major ports, plus most of the top trust ports privatised in the 1990s, privately owned ports now account for approximately $69 \%$ of UK tonnage.

\subsection{Trust ports}

A number of key ports in the UK remain administered as trust ports; for example, Dover, Milford Haven, Belfast and Aberdeen. As noted above, trust ports constituted the second wave of privatisation in the 1990s. The 1991 Act provided two processes for privatising a trust port. First, at the request of the port management, and second, directly by the Secretary of State, but this can only be done where the port has an annual turnover of over $£ 5 \mathrm{~m}$. A condition of the process is that the national government receives $50 \%$ of the sale price.

All cases so far except the port of Ipswich have been instigated by the ports themselves. Tees and Hartlepool, Clyde, Forth, Medway and London were sold in 1992, followed by 
Dundee in 1995. Late in the conservative administration, Dover, Tyne and Ipswich were directed to begin processes. The Ipswich sale was approved in 1997, and Tyne (which did not want to privatise) was cancelled later that year by the incoming Labour government. The port of Dover, the UK's busiest ferry port, handling around 5 million RoRo vehicles and over 13 million passengers annually, with a turnover of approximately $£ 60$ million, had indicated the intention to privatise but opposition from port customers and the local community led to ongoing wrangling over the form it should take. Therefore, the application was not submitted until 2010 and the coalition Conservative-Liberal Democrat government rejected the proposal in 2012, based on two primary reasons (House of Commons, 2013). First, insufficient community participation, and second, its rationale was for needing funds to expand the Western Docks, which it was viewed could be obtained by other means. In 2014 the port applied for a Harbour Revision Order (see section 4) to revise the status of the trust in order to increase the port's commercial ability. The minister granted the order which included the ability to sell port property, borrow against its assets and pursue joint ventures. The response from major customer $\mathrm{P} \& \mathrm{O}$ Ferries was that: "The Minister seems to have reached a pragmatic compromise, removing the port's rationale for privatisation by easing some of the financial restrictions that go with its Trust Port status" (Osler, 2014).

The Labour government published a guide to modernising trust ports in 2000 (DETR, 2000a) and it was updated in 2009 (DfT, 2009), the latter based partly on a report by consultants $\mathrm{PwC}$ on the operation of trust ports in 2007. The 2007 interim policy review (see next section) stated that "the $\mathrm{PwC}$ report concludes that the trust model retains a legitimate role within a mixed ports sector. . . . The report also concludes that, while the largest trust ports operate on a sound commercial basis, in some cases their financial performance falls short of that of their private sector comparators" (DfT, 2007; unpaginated). The Labour government, therefore, held a firm view on improving the commercial ability of trust ports through strategies other than privatisation: "This Government has stated that it does not wish to use its powers under the Ports Act 1991 to force through the privatisation of a port. Nevertheless the Department strongly encourages trust ports to analyse their corporate structure and keep it under review, with a view to identifying opportunities to enhance their efficiency and get value from their assets" (DfT, 2009: 26). In 2011 the new coalition Conservative - Liberal Democrat government consulted and then published a note on the criteria for deciding on the privatisation of trust ports (DfT, 2011). There were some revisions from previous criteria, notably the requirement for community participation, alongside future 
investment in the port, fair price and fair competition. Employee involvement was also desirable but not mandatory.

\subsection{Municipal ports}

While the vast majority of municipal ports are small harbours for leisure craft, a few have commercial significance, for example the privately operated oil terminals within the municipal ports of Sullom Voe and Orkney. The port of Bristol is unique in being technically a municipal port but effectively privatised since a private operator purchased a 150-year lease in 1991. Unlike trust ports, municipal ports are officially government assets, meaning that they are subject to reviews.

The Labour UK government published guidance for municipal ports in 2006, based on a survey of municipal ports in England and Wales (DfT, 2006), recommending that, although municipal ports are not trust ports, they could benefit from the recommendations given to trust ports regarding greater accountability and better financial management.

\section{Policy and planning for UK ports}

Goss (1997) reported on the closure of the National Ports Council (NPC) in 1981, which was not necessarily part of a move away from central control as the NPC was considered rather ineffectual. This was to some degree an inevitable result of the contradiction between central planning while also desiring competition between independent ports. Thus the NPC established in 1964 possessed a merely advisory role, with any decision making powers retained by the Department for Transport. In any case, the NPC and the DfT could only give or withhold permission for a proposed plan, not direct ports to make investments or expansions, therefore the national planning function was quite ineffectual and not missed when it was removed. Perhaps a more far-reaching outcome of the Harbours Act 1964 was the abolition of statutory controls on port dues. While such deregulation can be a major spur to industry development (e.g. the Staggers Act in the US rail industry), it remains a problem in the UK today that port users must appeal to the minister to challenge what they view as unfair port dues. Another significant outcome of this era was the amalgamation of many small ports within a single estuary into large trust port authorities, meaning that when these trusts were later privatised, they controlled all traffic on their respective rivers. While this does not necessarily preclude other (generally small) operators entering the market (see discussion of Table 1), the ownership of most port facilities by the incumbent operator and 
the conflict of interest inherent in their role as harbour authority act as significant barriers to entry, thus reducing competition.

Of greater significance than the sale of many UK ports was the 1989 abolition of the National Dock Labour Scheme (NDLS), thus ending the restriction of access to port labour to those registered in the scheme. It is widely acknowledged that the efficiency increase resulting from the abolition of this scheme has been more influential on the improved performance of UK ports than the change in ownership model. One of the key factors in the rise of Felixstowe was that, as it was too small to be included when the scheme was constructed, it was later able to progress towards containerisation without the limitation of negotiating with the staffing requirements of the scheme that other ports faced. Policy statements reveal that government views its role now as more about regulation of issues such as health and safety, giving or withholding planning approval for major developments and perhaps the occasional begrudging concession regarding how the public sector can support the industry where required, in rare cases involving direct investment.

Headicar (2009) notes that the UK Conservative government (1979-1997) had very little in the way of published transport policy and strategy but they still made significant changes to transport governance across the UK, including widespread privatisation of infrastructure and operations and centralisation of planning responsibilities. In contrast, the Labour government (1997-2010) published many documents with perhaps less clear result. Indeed, it was the Labour government that published the first UK port policy document in a generation, yet Modern Ports: A UK Policy (DETR, 2000b) simply confirmed the continuation of the previous government's light-touch approach. Despite promising to "support sustainable port projects for which there is a clear need, with each looked at in detail on its merits" (p7) and to "encourage the use of ports by coastal and short sea shipping services," (p7) the document stated clearly that "it is not the government's job to run the ports industry" (p5). The document also declared that "port infrastructure can and should be commercially financed," (p9) and "we believe that port developments and port operations should not in general need public subsidy. Public money is not well spent in distorting competition between ports" (p10). One outcome of the document was that in 2003 the DfT published A Project Appraisal Framework for Ports (DfT, 2003), which was intended to provide non-statutory but nonetheless highly recommended guidance for ports when preparing development proposals that would require government approval. Indeed, Pettit (2008: 723) noted that the lack of a national policy for strategic port development meant that "in the recent past, it is the 
development planning system that has had most impact on determining the development of UK ports."

The successor document, National Policy Statement for Ports (DfT, 2011) was planned by the Labour government and the first draft consulted on in 2009-10 but finally published by the coalition Conservative - Liberal Democrat government (2010-2015). It to some degree developed out of a 2007 interim review of port policy which had recommended that the government commission five-yearly demand forecasts, encourage the use of master plans for ports handling in excess of $1 \mathrm{~m}$ tonnes (for which guidance was produced a year later: DfT, 2008), safeguard port land and safety requirements and continue pursuit of trust port modernisation.

The Infrastructure Planning Commission (IPC) was a short-lived body created by the Labour government in 2009 based on the Planning Act 2008. It set thresholds for nationally significant infrastructure projects (NSIP), which would require to be referred to the IPC rather than handled directly by the government. These NSIPs could be in several policy areas such as transport or energy. The thresholds for ports were cargo throughput of 500,000 TEU, 250,000 RoRo movements or 5m tonnes of general or bulk cargo. As port developments also require marine licenses, the role of the IPC in port projects overlapped to some extent with the creation of the Marine Management Organisation (MMO) by the Marine and Coastal Access Act 2009, which was given power to grant Harbour Revision Orders (for port expansion) and Marine Licences (for dredging). While the IPC was abolished by the Conservative - Liberal Democrat coalition government in 2012 as a result of the Localism Act 2011, which returned decision making powers to government, the MMO remains in place.

The idea behind moving decision making powers out of the government was that it would speed up the decision making process as lengthy planning inquiries were blamed for the delay in approving capacity expansions in the early 2000s as the container market boomed. During this period, the UK lost some of its market share to continental ports due to a lack of capacity in the southeast of the UK, indicated by a decline in the UK range's share of European traffic, from over 15\% in 1996 to around 9\% in 2008 (Notteboom, 2010). It was also intended to reduce potential for politically motivated intervention, but decisions would nonetheless be guided by the outlines in the relevant National Policy Statements produced by government. Distinct from the rest of the UK, approvals in Scotland are granted by Transport Scotland (Harbour Revision Order) and Marine Scotland (Marine Licenses). The previous planning 
process, which in many cases entailed lengthy inquiries, received heavy criticism (e.g. Asteris and Collins, 2007), yet Southampton's Dibden Bay development remains the only major scheme to have been rejected.

The 2011 national ports policy statement mentioned above is, therefore, less a ports policy and more a document for guiding planning decisions made by the IPC, which, by the time the document was published, was already in the process of being disbanded. The document has little to say about the operation of current private ports nor the management of trust or municipal ports. The document confirms the view that it is not the role of government to plan and build ports but simply to approve or reject development proposals and ensure ports meet their "legal, environmental and social constraints and objectives" (p11). However, it does mention the need "to cater for long-term forecast growth" (p11). The document is clear that, while it is the decision of individual ports whether to invest in expansion, the list of currently approved expansions would be more than sufficient to cater for projected demand "over the next 20 years or so" (p14). While the document contains many pages of guidelines, including the need to conform to any existing marine plans, habitat species regulations and requiring an Environmental Impact Assessment, it is clear that decision-makers "should start with a presumption in favour of granting consent to applications for ports development" (p17). Such a major development will also generally involve a public enquiry to hear objections and all of this will go into the final application seeking approval by the government in the person of the Secretary of State for Transport in the UK for English and Welsh ports or the Transport Minister in the case of ports in Scotland or Northern Ireland.

\section{Recent port developments}

As shown above, the UK government takes a very light touch approach to port governance. Day-to-day port operations as well as investment and expansion are the decisions of the individual ports, whether private, trust or municipally owned and operated. In order to consider the outcomes of this governance model, some recent developments will be discussed in this section.

\subsection{New port developments}

Many UK ports have recently completed or are planning major developments, both to increase total handling capacity but also to increase depth and crane size to handle the increasing size of container vessels. This applies both to the top end of the market but also to 
the increasing size of feeder vessels, thus giving ports like Teesport a competitive advantage over other east coast feeder ports (Wilmsmeier and Monios, 2013).

The expansion of container capacity at Felixstowe to 5.5m TEU was approved in 2006 after initial application by HPH and public inquiry in 2004. The first phase, including 730m of quay with 16m depth alongside, was completed in 2011 and the 190m extension in 2015 will allow the port to handle two ultra large container vessels simultaneously. The port has also expanded its rail operations by developing a second rail terminal, achieving rail throughput of 890,000 TEU in 2014 , accounting for a $22 \%$ modal share. An additional expansion plan of $1.7 \mathrm{~m}$ TEU by HPH at their neighbouring port at Bathside Bay (Harwich) was also approved on a similar timeline, although due to the recession this development was never taken forward, and potential challenges to renewing the permission suggest it is unlikely to be raised again.

Southampton's proposal for a new container terminal at Dibden Bay with a capacity of $2.3 \mathrm{~m}$ TEU was rejected in 2004 after a lengthy planning and inquiry process lasting almost three years and costing an estimated $£ 45 \mathrm{~m}$. The decision was that the significant negative impact on the environmentally sensitive areas was not outweighed by the country's pressing need in the early 2000s for increased container handling capacity. More than any of the others, the lengthy delay in this process was one of the main catalysts for reforming the planning system for major ports. The port has since progressed with development within its existing footprint and necessary dredging of the access channel, taking capacity from $2 \mathrm{~m}$ TEU to $2.7 \mathrm{~m}$ TEU. Permission was initially granted by the MMO in February 2011, but subsequent legal challenges by HPH caused delays and the project was finally approved in May 2012.

The entirely new container terminal by P\&O (now DP World) at London Gateway on the site of an ex-Shell oil refinery on the Thames to the east of London was approved in 2007 after an initial application in 2002 and public inquiry during 2003. As it is a new port rather than an expansion, it required a Harbour Empowerment Order rather than a Harbour Revision Order. The port opened in 2014 with a first phase capacity of $1.6 \mathrm{~m}$ TEU (with a final goal of $3.5 \mathrm{~m}$ TEU). The marketing position is that it is best-placed to serve the UK's largest consumption zone (London and the southeast UK) as well as competing with the UK's primary container port Felixstowe for deepsea cargo destined for traditional distribution locations in the centre of the country. 
Besides these developments at the dominant deep sea ports, major port developments have also been approved at Liverpool, Teesport and Bristol. Liverpool is currently the fourth busiest container port in the UK, receiving deep sea calls from across the Atlantic, but hoping eventually to attract Asian links. Its 2014 throughput was 666,000 TEU, and the development of a new container terminal is being pursued that would add approximately 600,000 TEU capacity to the current limit of around $1 \mathrm{~m}$ TEU. The new terminal, linked to a dredging of the access channel, will be able to handle vessels up to 13,500 TEU, compared to the current limit of 3,500 TEU. The project was approved in 2012 after a short consultation with no objections, construction commenced in 2013 and the terminal is due to open in 2016.

Teesport had already upgraded the container terminal in 2003 to a capacity of 235,000 TEU. The port applied in 2006 for further expansion, and no enquiry was needed due to a lack of objections. Approval was given by the government in 2008 . The port invested $£ 16.7 \mathrm{~m}$ in expanding the second container terminal, increasing total handling capacity to around 500,000 TEU by 2011. In 2014 the port handled 304,000 TEU. Further expansion is planned in stages, with a long-term target of $1.5 \mathrm{~m}$ TEU.

Compared to these ports, Bristol is currently a small container port (106,000 TEU in 2014 ), yet $£ 600 \mathrm{~m}$ is being invested in a new deep-sea container terminal with a capacity of $1.5 \mathrm{~m}$ TEU. It went through a public inquiry in 2009 and was approved in 2010. In Scotland, a new container terminal has been proposed by Babcocks for the port of Rosyth, aiming initially for capacity of 450,000 TEU, and future expansion to 600,000 TEU. The Harbour Revision Order for the port development work was approved by the Scottish transport minister in 2013 after a public inquiry to hear objections including environmental objections from the RSPB and from competitor Forth Ports who operate Grangemouth. Work has not yet commenced on the proposed development, as the port also needed to obtain a separate Marine Licence to approve dredging the access channel.

The trust port of Aberdeen is the centre of supply for the oil rigs. It handled $4.2 \mathrm{~m}$ tonnes of traffic in 2014 including 33,000 TEU of containers, with a turnover of $£ 28.9 \mathrm{~m}$. Due to port congestion which has seen some of its oil support traffic migrate to Montrose, the port is seeking approval for expansion into Nigg Bay with a £410m development. In late 2015 it submitted formal applications for a Harbour Revision Order and Marine Licence. The project already has Scottish government support as it was included in the third National Planning Framework. 


\subsection{Discussion}

The numerous port developments discussed above suggest that not only the larger ports but also regional ports expect increased traffic in the coming years. In the past, UK ports were considered to be short of capacity, but the danger now is quite the opposite.

The port of Liverpool is spending $£ 300 \mathrm{~m}$ to build the Liverpool 2 container terminal, in order to be able to handle larger container vessels. While their rationale that much of the UK's container demand is closer to Liverpool than to the southeastern ports is sound, it is a question of whether the ships will divert from the major trade lanes to serve Liverpool rather than the current model whereby vessels traverse the shortest route to northwest Europe and the containers then must travel overland from southern UK ports to their destinations. This development is linked to other major investment, such as new warehousing, biomass silos and an inland port and logistics facility on the Manchester Ship Canal, which would be the UK's only inland waterway container port. A positive indicator for this development is that even before the new terminal has been opened, Maersk subsidiary Seago is now linking Liverpool with Mediterranean transhipment hub Algeciras, representing the first call by Maersk at the port in over a decade. It is also interesting that in 2013 Sefton Borough Council received $£ 35 \mathrm{~m}$ from the UK government's Regional Growth Fund towards the cost of dredging the access channel to $16 \mathrm{~m}$. While the grant was officially to the council rather than the port, the new terminal is obviously the major beneficiary. The rationale for the use of public money for port development was based on the creation of jobs in both the building works and from the increase in future traffic. Unsurprisingly, other ports were unhappy with what they viewed as a diversion from the UK port policy that stated that ports should fund their own development, which indeed raises its own governance issue regarding the relationship between investment that is purely for the benefit of port operations and investments that benefit the wider public good. If the port land and infrastructure is publicly owned then it is easier for the government to make such investment decisions because no individual concessionaire would benefit unduly vis-à-vis any other as the quality of both the port and connecting infrastructure would be factored into the concession deal.

The development of Teesport is evidence of a proactive port seeking to expand its feeder capacity as well as direct European shortsea traffic, benefiting from the growth of exports from countries such as Poland as some elements of manufacturing are "reshoring" from the Far East to Eastern Europe. Figure 4 shows the competition between secondary container ports in the UK and the success of Teesport. As the port of Grangemouth cannot accept 
vessels much larger than 1,000 TEU due to depth and lock restrictions, Teesport now has an on-dock rail facility with container shuttles to Scotland. As the port can handle vessels up to 3,500 TEU, it could accommodate some feeder vessels that may cascade down once larger vessels enter service on the mainlines (Monios, 2015), making it well-placed to compete for feeder cargo across the north of the UK, including Scotland. It is also interesting that the Rosyth container port development was included in the Scottish government's third National Planning Framework, though it was watered down from a specific mention of Rosyth in the draft document to a less specific "additional container capacity in the Forth" in the final version.

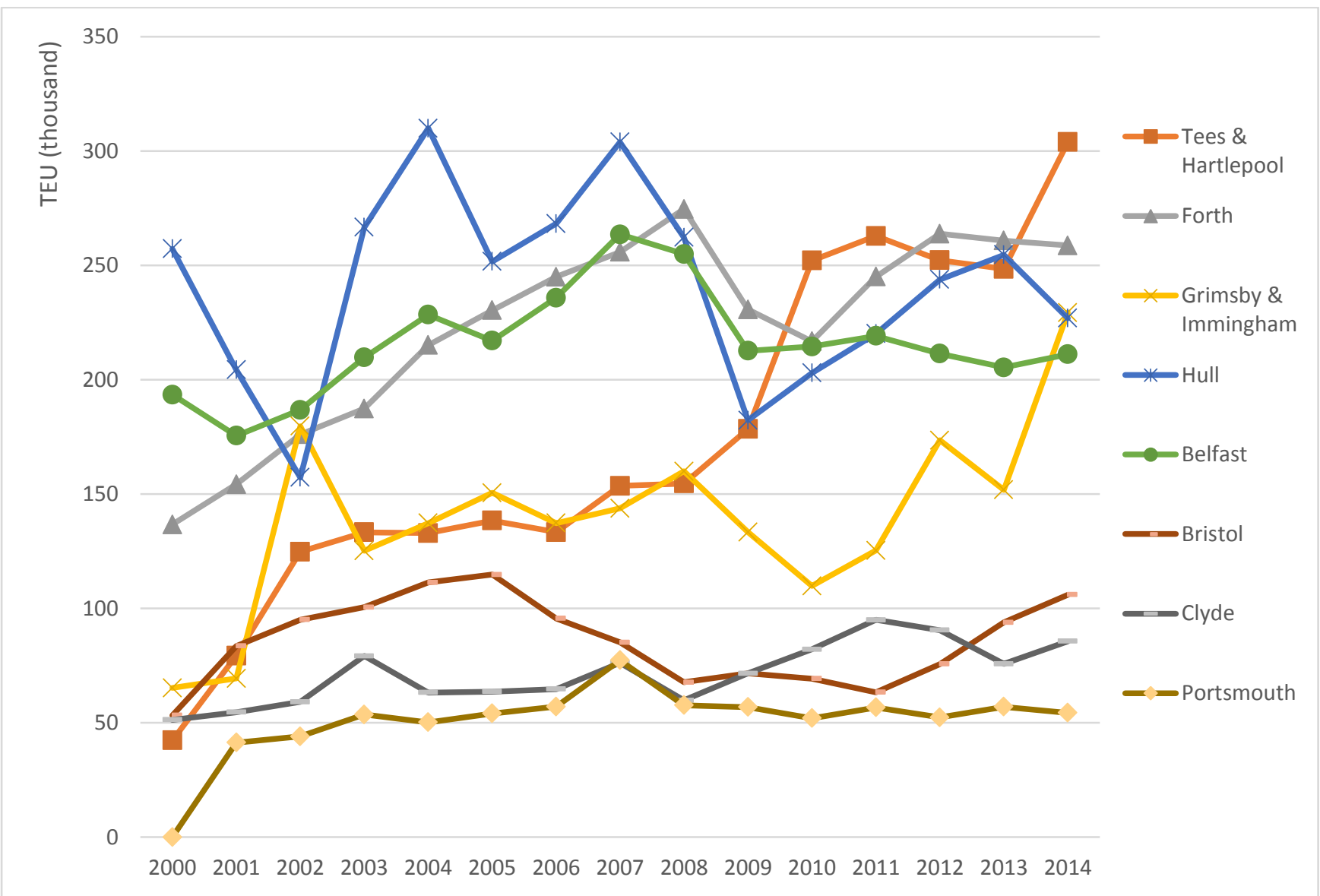

Figure 4. Throughput at secondary UK container ports, 2000-2014

While UK ports have only an indirect role for the most part in hinterland transport, not choosing to invest in inland terminals in the same way that some of their counterparts have in mainland Europe (although ABP does own Hams Hall, Birmingham), there is some evidence of ports taking a more direct role in terms of logistics. The phrase "port-centric logistics" is 
heard often in the UK (Mangan et al., 2008; Pettit \& Beresford, 2009; Monios \& Wilmsmeier, 2012), mostly with regard to Teesport, which has been the market leader in terms of port-centric strategy. While it still handles significant non-unitised trade (such as steel and chemicals), it has used ex-brownfield land vacated by the decline of traditional industries to attract consumer goods to the port. Major retailers Asda (500,000 sq. ft., opened 2006, 30 year lease) and Tesco (900,000 sq. ft., opened 2009, 125 year lease) opened importfocused distribution centres (DCs) inside the port for product lines such as clothing and electronics, even though their grocery lines remained based in their Midlands DCs. Other firms have located DCs inside and in the vicinity of the port; in the latter case, big box retailer Argos located near the port, and their carrier changed their port choice from the large south-eastern ports in order to reduce land transport costs. Plans for the creation of a further $1.6 \mathrm{~m}$ sq. $\mathrm{ft}$. of distribution space are now in place. Some challenges have arisen, however; Tesco no longer ships containers through this port, instead bringing containers from the ports of Felixstowe and Southampton, which indicates that even with port-centric strategies, centralisation tendencies are difficult to overcome. This is partly because Tesco has fewer stores in the northeast than Asda so the port-centric strategy was not suitable to their store coverage.

The London Gateway case is interesting because it could be considered to lead to overcapacity at a time when demand is weak. Its plans for a 9.25 million sq ft. port centric logistics area have also struggled. The key clients for this were Marks \& Spencer and Uniserve who had each agreed to build a 900,000 sq. ft. DC in the port, but withdrew. The port is, however, in talks with other clients and some DCs in the range of 100,000-400,000 sq. ft. are expected to begin construction soon. While concerns had already existed regarding whether the UK required such a level of additional container handling capacity, there also appears to be some reluctance for the logistics sector to anchor their distribution activities at this location. Yet due to the heavy storms in early 2016, London Gateway was able to handle vessels diverted from Felixstowe, thanks to its sheltered upstream location. Indeed, with increased frequency of bad weather events expected in future, upstream ports may be able to reassert their traditional advantage over more exposed coastal locations favoured in more recent times for new deep water terminal developments.

In conclusion, the Liverpool case shows that public money is still available for port developments in the UK, subject to certain conditions. It also shows that private ports can seek to expand to win new traffic rather than merely sweating assets. The attempts by Peel 
Ports to expand Sheerness and make use of the Manchester ship canal also indicate new directions. The Teesport case also indicates substantial appetite for growth, while its success against Grangemouth indicates the difference in strategy between a private port with competition and a private port with a local monopoly. Because Grangemouth has sufficient captive cargo, it is not incentivised to invest in what its management presumably views as potentially speculative competition with Teesport, a short-term view which may lead to longer term decline. Similarly, Teesport is not investing purely to compete with Grangemouth but mostly for competing with closer ports, with the added bonus of making itself attractive to cargo currently served by Grangemouth. London Gateway is in some ways indicative of overcapacity and their difficulties in securing tenants for the port centric strategy may reflect wider trends. But its good location and facilities will likely bear fruit in the longer term.

The decision on the Dover case is curious because, given the previous privatisation programme, it might have been expected that the government would have accepted the port's request to privatise. Part of the refusal decision related to the role of other stakeholders, particularly the local community, which had been stridently against the motion. Therefore there is some evidence of the community shaping port governance rather than a purely topdown ideological privatisation drive.

\section{Governance issues in the UK port system}

The advantages of greater private sector involvement in ports derive primarily from increased efficiency and reduced cost to the public sector. Negative impacts include the loss or increased ambiguity of state control as well as the difficulties and risks involved in managing the sale or tender process and subsequent monitoring (Baird, 2002). Debrie et al. (2013) argued for a deeper contextualisation of port governance models, considering the institutional context (relationship between public and private actors and relative decisionmaking powers) as well as characteristics of the local market and societal and cultural factors impacting on motivations for public intervention. Some of these issues can be identified in the above analysis.

From the national perspective, all UK ports are self-governing, most of the major ports being either private or administered by trusts. Ports are responsible for their own planning and development, subject to approval for major works as discussed in the previous section. Compared to other countries which follow the landlord model and thus retain some influence on port management, the role of the government in the UK is necessarily indirect, called to 
intervene in disputes over unfair charges levied by harbour authorities or to deal with industry complaints regarding light dues.

As with any change in governance, questions are raised regarding the initial aim. If privatising is intended to bring in competition, in many cases this was not possible due to geographical factors, such as estuary monopolies and single-cargo sites such as oil terminals. Full privatisation without restriction on land use also enabled port owners to sell valuable assets such as port land and in some cases potentially extract economic rents through their combined harbour authority and landowner status. A lack of government oversight on the activities and pricing policies of harbour authorities means that an authority can levy a series of charges for pilotage, towage, etc. that may or may not be basically economic rent as the user has no choice but to pay. This problem is exacerbated in cases where the port operator is also the harbour authority.

While Farrell (2013) argued that the future profitability of ports and in particular the future value of their land could not have been foreseen in the early 1990s, similar arguments could be applied to many countries which nevertheless opted for a landlord model rather than privatisation (Goss, 1997). The fact that, even today, privatisations continue to be undervalued suggests either an inability to learn from history or an ideological position in favour of low valuations to get the items off the government balance sheet. The privatisation of the UK Royal Mail in 2013 was marked by a 38\% increase in share price on the first day of trading, rising some months later to $87 \%$ above the government valuation. By privatising ports and retaining little leverage over future directions due to selling off the land in its entirety with no conditions as to future operations, it seems more likely that the motivation was to remove the assets from the public sector rather than to stimulate new investment or competition. The UK case therefore supports the view that the selection of governance model is not always related to port performance, and that "while governments may have had the best intentions in establishing a more commercialized footing for port operations, the programme of reform has not always delivered the full benefits sought" (Brooks \& Pallis, 2008: 413). In the absence of a comprehensive review of the performance of UK private ports, suggestions from some users that not all ports are delivering those performance benefits cannot be confirmed or, more importantly, addressed. The Scottish case in particular reveals an example of a local monopoly. Similarly, full privatisation means that ports can later be sold on, reflecting the trend towards oligopoly in many privatised transport sectors, such as bus 
and rail in the UK. This is also reflected in the global trend in the port sector towards oligopoly in both ports and shipping lines.

One could argue from a theoretical position that ports obtain much of their ability to earn profit from natural endowments thus the country should earn its share of those profits by retaining a landlord function, or, to put it another way, to ensure that supernormal profits are not earned in the first place, thus providing lower cost services to port users and benefiting the country in that way. Using the language of economics, the goal would be to prevent port operators extracting economic rents from the inelastic fixed input represented by their location (Goss, 1999). It could be possible for the government to levy some kind of windfall tax on supernormal profits, but the political acceptability of such a move would be extremely challenging, as would the benchmarking process to establish the tax rates. As Goss (1999: 5) put it: "Those parties interested in retaining their quasi-rents may attack, or seek to frustrate, any objective indicators of efficiency."

The opposing ideological position is that it is not the business of government to provide transport services. In the UK case it remains something of a moot point as no government is going to spend the billions required to purchase the ports back, nor are they going to force private operators to become not-for-profit trusts. This would amount to the same as purchasing the ports as any transformation to trust status could only be achieved by compensating the private shareholders. Even if such moves were undertaken, the next government needing funds would sell them again. Nationalisation only happened in response to a unique situation, i.e. the aftermath of world war two. It is not going to happen again without similar incentive. Renationalising the passenger rail industry, privatised by the Conservatives in 1993, enjoys significant popularity with Labour voters, yet the Labour government made no moves in this direction throughout 13 years in office, which indicates the lack of government appetite across the political spectrum for such a policy.

Moreover, any discussion of private vs public must consider the scale of public control, and recognise the difficulties of national planning for independent locally operated ports. As seen in the difficulties of centralised planning experienced by the 1964-1981 National Ports Council, many of the privatised ports were actually former trusts, thus never managed at the national level. The encouragement in more recent times for all major ports to prepare master plans was intended to allow some kind of national monitoring (but not management) of the port network, and "assist regional and local planning bodies, and transport network providers, in preparing and revising their own development strategies" (DfT, 2008: 4). Other countries 
such as Italy and Germany are experiencing similar difficulties regarding how to decide at national level which ports should get investment when in many cases there is no net benefit to the country from several similar expansions for ports competing for the same hinterland.

A fact transcending political ideology is that a well performing port industry is in the interests of all stakeholders. What the government can do, then, is protect the nation's interests by using regulation to ensure equitable development, good performance and fair charging. Baird and Valentine (2007) note that, unlike the other privatised utilities in the UK, such as gas and water, there was no equivalent body established to regulate the port industry. While the government does say it will respond to complaints, it could be more proactive about measuring and managing the process. While government reviews of trust ports (2000, 2009) and municipal ports (2006) have been undertaken, no similar review has been undertaken of the operation of private ports (Baird and Valentine, 2007), although a national port forecast was produced by MDS in 2006, and to some degree has been used in deciding approvals of major port capacity upgrades. For example, the Dibden Bay development was rejected because the large environmental damage was not considered to be offset by the addition to national port capacity, as sufficient total capacity was deemed to be coming onstream from other already approved developments. Then again, some have criticised this approach as it is to some degree subjective by relying on other developments rather than judging the individual proposal on its own merits. So, the government can be seen to have taken a view on total capacity provision from the national level, although this does not include a review of performance.

Baird (2016) proposes that the government should intervene, estimate how much capacity is needed and where, and if it is not being provided then build it (through concession). Using a national port regulator to institute performance reviews and penalties would be a better way to incentivise new development and expansion. Not only would it improve the performance of existing ports, but it would incentivise market entry if an incumbent port is unable to meet its performance targets and having to pay fines, etc. and another operator believes that they could provide equivalent services for less cost. Planning system reform can be argued to have improved the incentives to develop and indeed the sector as a whole faces over capacity, so the pressing governance task now is not capacity but performance.

\section{Conclusion}


It is difficult to evaluate the effects of a given port governance model on trade as, once the change has been made at a particular port, their unique situations mean that there is no longer any control group against which it can be compared. In any case, as long as sufficient total port capacity exists then trade in a region will be served. One can argue whether the market is providing port capacity in the right places and whether trade is diverted to other ports hence incurring increased costs, but new port capacity may not necessarily change this situation, depending on a range of influencing factors such as the call choices of shipping lines, location of shippers and centralised distribution strategies. If ports are being served and trade is flowing and industry complaints are low then government policy makers will consider their model endorsed, with little incentive for governance reform.

Lack of reform incentive is further entrenched once the majority of the sector has been privatised, where levers for direct influence are reduced. Therefore, in recent years the role of the UK government in the management of ports has been evident mostly through regulation of activities, granting or withholding of planning permission for new developments and expansions and, in the case of Liverpool, direct investment.

Would a different model have avoided the under capacity problem in the early 2000s which saw the UK lose some market share to continental Europe? Would it have avoided the subsequent overcapacity, whereby delayed expansions all came on stream during a recession? Governments are not necessarily any better at forecasting future supply needs than the private sector (see the MDS forecasts which predicted continuous growth before the recession hit). What the government should, however, be able to do is regulate quality of provision. There is some evidence that this is not being done, and, while the government says it will respond to such issues, it should be more proactive about measuring and managing this issue.

It remains difficult to provide a definitive answer to the question posed by Brooks and Cullinane (2007: 412) regarding "the determination of whether highly prescriptive or loosely guided approaches are more effective in generating strong performance." Certainly neither proscriptive nor loose approaches are possible in the absence of the appropriate levers, and it is politically difficult to institute them once they have been given up or been unused for long periods. What is clear is that competition is necessary to drive investment and improve performance, as evidenced by the east coast of England compared to Scotland. Inviting private participation is only likely to work if strong incentives exist to innovate and invest, i.e. not in natural monopoly situations. While Baird (2013) is correct to criticise the high levels of both debt and profits evidenced in the private equity ownership of many UK ports, 
lack of investment is not always the result. The port development plans discussed in this paper (e.g. Liverpool and Teesport) suggest that such operators will invest in the presence of appropriate incentives, as also noted by Farrell (2013).

Public regulation provides minimum standards, although some evidence suggests that this model allows operators to play the system to some extent as it is time consuming and expensive to follow up and they know that. At a recent inquiry in Scotland, the operator of one port said that "at present our customers are very happy with the service that we provide", while one of their customers said "If there were an alternative, we would easily switch to someone else straight away" (Infrastructure and Capital Investment Committee, 2015). Therefore, while it is easy to say that the current system works, there is clearly a service quality issue with no levers to address it, or at least government unwilling to do so. A first step might be, as Baird (2016) suggests, to establish a national port regulator to monitor performance and ensure the nation's interests are being served, perhaps extended to include not just monitoring of port operational quality but to cover harbour authority functions. Expecting public organisations to take responsibility for pursuing proactive port development, on the other hand, is likely to prove more challenging.

\section{References}

Asteris, M., Collins, A. (2007). Developing Britain's port infrastructure: markets, policy and location. Environment \& Planning A. 39 (9): 2271-2286.

Baird, A. J. (1995). Privatisation of trust ports in the United Kingdom: Review and analysis of the first sales. Journal of Transport Policy. 2 (2): 135-143.

Baird, A. (2002). Privatization trends at the world's top-100 container ports. Maritime Policy \& Management. 29 (3): 271-284.

Baird, A. (2013). Acquisition of UK ports by private equity funds. Research in Transportation Business \& Management. 8: 166-169.

Baird, A. (2016). Increased trade and economic growth won't happen in Scotland till we sort out our ports. The Jimmy Reid Foundation: Edinburgh.

Baird, A., Valentine, V. F. (2007). Port privatisation in the United Kingdom. Research in Transportation Economics. 17: 55-84.

Brooks, M., Pallis, A. A., 2008. Assessing port governance models: process and performance components. Maritime Policy \& Management. 35 (4): 411-432. 
Brooks, M. R., Cullinane, K. (Eds.), 2007. Devolution, Port Governance and Port Performance. Elsevier, London.

Debrie, J., Lavaud-Letilleul, V., Parola, F., 2013. Shaping port governance: the territorial trajectories of reform. Journal of Transport Geography. 27, 56-65.

DETR. (2000a). Modernising trust ports: a guide to good governance. DETR: London.

DETR. (2000b). Modern ports: A UK policy. DETR: London.

DfT. (2003). A project appraisal framework for ports. DfT: London.

DfT. (2006). Opportunities for ports in local authority ownership. DfT: London.

DfT. (2007). Ports policy review interim report. DfT: London.

DfT. (2008). Guidance on the preparation of port master plans. DfT: London.

DfT. (2009). Modernising trust ports. $2^{\text {nd }}$ ed. DfT: London

DfT. (2011). National policy statement for ports. DfT: London

DfT (2015). UK port freight statistics. DfT: London.

Farrell, S. (2013). Private equity in UK ports: an alternative view. Research in Transportation Business and Management. 8: 166-169.

Goss, R. (1997). British ports policies since 1945. Journal of Transport Economics and Policy. 32 (1): 51-57.

Goss, R. O. (1999). On the distribution of economic rent in seaports. International Journal of Maritime Economics. 1 (1): 1-9.

Headicar, P. (2009). Transport Policy and Planning in Great Britain. Abingdon, Oxon: Routledge.

House of Commons. (2013). Ports: privatisation of trust ports. House of Commons Library: London.

Infrastructure and Capital Investment Committee. (2015). Inquiry into freight transport in Scotland. Scottish Parliament: Edinburgh.

Mangan, J., Lalwani, C., Fynes, B., 2008. Port-centric logistics. The International Journal of Logistics Management. 19 (1): 29-41.

Monios, J. (2015). Cascading feeder vessels and the rationalisation of small container ports. Paper presented at the annual conference of the International Association of Maritime Economists (IAME), Kuala Lumpur, August 2015.

Monios, J., Wilmsmeier, G. (2012). Port-centric logistics, dry ports and offshore logistics hubs: strategies to overcome double peripherality? Maritime Policy and Management. 39 (2): 207-226. 
Notteboom, T. E., 2010. Concentration and the formation of multi-port gateway regions in the European container port system: an update. Journal of Transport Geography. 18 (4): $567-583$.

Osler, D. (2014). Dover given greater commercial powers but no sell-off. Lloyd's List. $9^{\text {th }}$ April 2014. https://www.lloydslist.com/ll/sector/ports-and-logistics/article439840.ece Accessed 8th April 2016.

Oxford Economics. (2015). The economic impact of the UK maritime services sector: ports. Oxford Economics: Oxford.

Pettit, S. J., 2008. United Kingdom ports policy: Changing government attitudes. Marine Policy. 32 (4): 719-727.

Pettit, S. J., Beresford, A. K. C., 2009. Port development: from gateways to logistics hubs. Maritime Policy \& Management. 36 (3): 253-267.

Saundry, R., Turnbull, P. (1997). Private profit, public loss: the financial and economic performance of UK ports. Maritime Policy \& Management. 24 (4): 319-334.

Thomas, B. J. (1994). The privatization of United Kingdom seaports. Maritime Policy \& Management. 21 (2): 135-148.

Wilmsmeier, G., Monios, J. (2013). Counterbalancing peripherality and concentration: an analysis of the UK container port system. Maritime Policy \& Management. 40 (2): 116132. 